\title{
Groundwater Resources Assessment for Sustainable Development in South Sudan
}

\author{
Manuela Lasagna ${ }^{1,2} \mathbb{1}$, Sabrina Maria Rita Bonetto ${ }^{1,2, *} \mathbb{1}$, Laura Debernardi ${ }^{1}$, \\ Domenico Antonio De Luca ${ }^{1,2}\left(\mathbb{0}\right.$, Carlo Semita ${ }^{1,2}$ and Chiara Caselle ${ }^{1}(\mathbb{C}$ \\ 1 Earth Sciences Department, Turin University, 10125 Torino, Italy; manuela.lasagna@unito.it (M.L.); \\ laura.debernardi@unito.it (L.D.); domenico.deluca@unito.it (D.A.D.L.); carlo.semita@unito.it (C.S.); \\ chiara.caselle@unito.it (C.C.) \\ 2 CISAO, Interdepartmental Centre of Research and Technical and Scientific Cooperation with Africa, \\ Turin University, 10125 Torino, Italy \\ * Correspondence: sabrina.bonetto@unito.it
}

Received: 29 May 2020; Accepted: 8 July 2020; Published: 10 July 2020

\begin{abstract}
The economic activities of South Sudan (East-Central Africa) are predominantly agricultural. However, food insecurity due to low agricultural production, connected with weather conditions and lack of water infrastructure and knowledge, is a huge problem. This study reports the results of a qualitative and quantitative investigation of underground and surface water in the area of Gumbo (east of Juba town) that aims to assure sustainable water management, reducing diseases and mortality and guaranteeing access to irrigation and drinking water. The results of the study demonstrate the peculiarity of surface and groundwater and the critical aspects to take into account for the water use, particularly due to the exceeding of limits suggested by the WHO and national regulation. The outcomes provide a contribution to the scientific overview on lithostratigraphic, hydrochemical and hydrogeological setting of a less-studied area, characterized by sociopolitical instability and water scarcity. This represents a first step for the improvement of water knowledge and management, for sustainable economic development and for social progress in this African region.
\end{abstract}

Keywords: water resources; sustainable management; local development; water for food security

\section{Introduction}

Environmental sustainability plays a major role in the United Nations (UN) Agenda 2030 for Sustainable Development. In this framework, the balance between protecting environmental resources and satisfying social and economic needs has become a key development issue.

The global variety of ecosystems and landscapes and the different accessibility to natural resources contribute to shaping social and economic factors, which affect the development of local territories and communities, providing special inputs to their economic growth and resilience. The critical relationship between economic development, growth and environmental protection, if not reconciled in sustainable ways, risks causing the depletion of natural resources.

In South Sudan, as in several Sub-Saharan African countries, environmental conditions are often vulnerable to several shocks (climate, population growth, human activities impact, conflicts and security), which may produce heavy effects on their development.

Many development projects, such as the project "Women Empowerment and Sustainable Agricultural Development to Achieve Food Security in South Sudan (WOSA) AID 10915" funded by the Italian Agency for Cooperation and Development (AICS), support the sustainable management and use of natural resources through actions for protecting water, air and soil, and for preserving biodiversity and combating desertification, including the elaboration and implementation of measures 
for mitigating the effects of climate change and for fostering resilience. Other important activities concern the energy and infrastructure sector, which includes transportation and water networks, the distribution of electricity generated by renewable resources and the broad sector of territorial planning.

In developing these approaches, the environmental characterization is promoted to identify landscape character types, geological stratification, biogeographical regions, etc. The recognized spatial frameworks would be useful in assessing interventions and impacts of policies to ensure local food security, social development and sustainable natural resources management. This information should be shared with local administrations, with the scientific community and with any organization that operates in the area.

The economy of South Sudan (East-Central Africa) is predominantly agrarian, with almost $60 \%$ of the total workforce engaged either directly or indirectly in agriculture. However, this sector remains underdeveloped due to the political instability of the country and the primitive method of farming systems. Food insecurity is a major problem due to low agricultural production connected with weather conditions and lack of water infrastructure and knowledge [1].

For these reasons, the present study aims to propose an analysis of the local hydrogeological framework in order to answer to the main needs linked to the deficit in the food production and to guarantee a sustainable access to irrigation and drinking water, reducing diseases and mortality.

The study focuses on the city of Gumbo, located at the east side of Juba town. Juba is divided into three sub-districts named Sherikat (Central Gumbo), Jebel Lemon (east of Gumbo) and Adodi (North-West Gumbo). The population of Gumbo is roughly 5000 households, and more than $70 \%$ of the population depends on agriculture. About $80 \%$ of the population comes from different parts of the country, particularly from east side of Juba. They are internally displaced persons or refugees as a result of the civil war, which broke out in December 2013, and its impact.

The aim of this work is to provide a hydrogeological, lithostratigraphic and hydrochemical reconstruction of the area. These activities are useful for programming drilling campaigns of new wells and in defining sustainable uses or interventions for water according to the quality [2-10]. The shortage of previous studies in the area, also due to the long civil war that occurred in the region in recent years, makes particularly important the collection and the organization of available scientific knowledge on the territory and the execution of new studies to fill the gap of data at the local scale. This may help to create a database for the necessary future interventions that have to be planned in the area.

The study is organized as a first collection of geologic and hydrogeological data of South Sudan, starting from the scarce literature that was completed with a more detailed lithostratigraphic and hydrogeological analysis, specifically focused on the area of Juba.

\section{Material and Methods}

\subsection{Collection of Information on the Study Area from the Scientific Literature}

The collection of geological and hydrogeological information on South Sudan started from the scarce available scientific literature and brought to the reconstruction of a general framework of the climate, the vegetation and the regional geological and hydrogeological setting. The absence of more detailed data at the local scale was filled with a lithostratigraphic, hydrogeological and hydrochemical reconstruction in the area of Juba, the capital of South Sudan. Specifically, the proposed study focuses on an area surrounding Gumbo (Central Equatoria-Payam Rajaf) (Figure 1), which is located in a flat plain at a distance of about $1.5 \mathrm{~km}$ eastwards from the Nile River, referred to here as the "White Nile". 


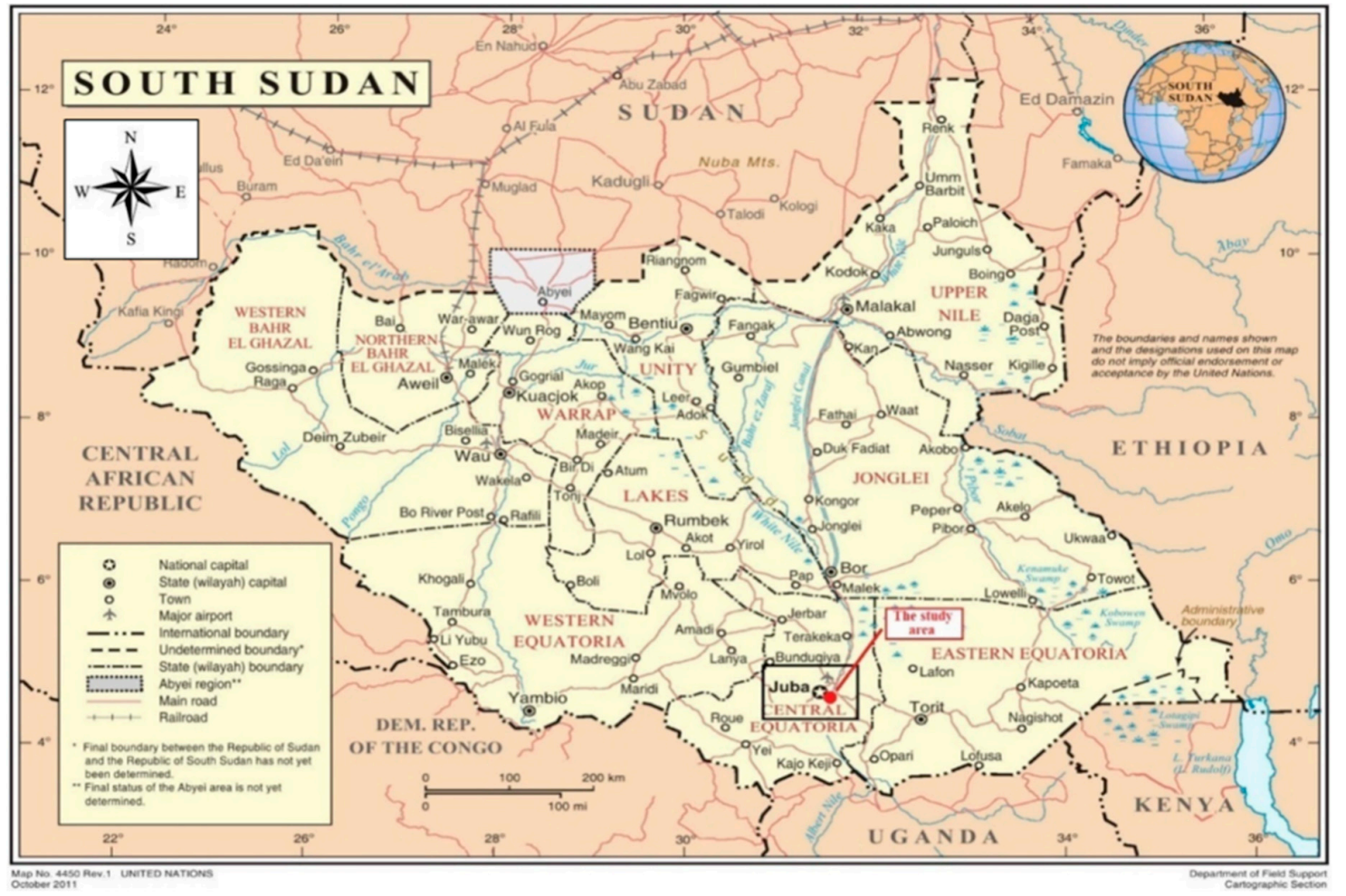

Figure 1. Location of the study area (modified from [11]).

\subsection{On-Site Survey}

\subsubsection{Lithostratigraphic Reconstruction}

The lithostratigraphic reconstruction was conducted combining data from a geophysical survey, performed in August 2017 by the United Drilling Company, and from the execution of four new wells drilled in 2018.

The geophysical survey was implemented in an area suffering from lack of water (Figure 2). It consisted of two vertical electrical soundings (VESs), which provided an insight into both thicknesses and types of the overburden strata and of the presence of fractured bedrock, based on resistivity contrasts. VESs were conducted using potential electrode spacing (MN/2) of 0.5 and $5 \mathrm{~m}$, reaching a depth of about $50 \mathrm{~m}$.

\subsubsection{Hydrogeological Reconstruction}

The new wells were drilled in areas where people lived without free access to water for human, agriculture and livelihood consumption (WPC, W1, W2, W3 in Figure 2). The depth of wells ranges between 60 and $90 \mathrm{~m}$. Stratigraphic logs and water table levels (meters below ground level, $\mathrm{m} \mathrm{b.g.l.)}$ contribute to the stratigraphic and hydrogeological reconstruction. Water table levels of spring-summer 2018 were interpolated to create a preliminary water table map, indicating the main flow direction of groundwater.

\subsubsection{Hydrochemical Analyses}

The reconstruction of the hydrochemical setting was performed through two sampling campaigns, conducted in August 2017 (1 water sample, called WPC) and July 2018 (6 water samples). This second campaign includes both groundwater samples (W1, W2 and W3) and surface water samples, taken from seasonal streams (S1, S2 and S3) (Figure 2). Due to the political instability, military checkpoints conditioned the mobility of persons and vehicles, limiting the access to many areas, particularly along 
the main streams. Hence, the sampling was only performed for the new drilled wells (groundwater) and areas of free access (seasonal streams samples).

The chemical analyses, performed by the Nuovi Servizi Ambientali (NSA) laboratory in Robassomero (Turin, Italy), included a first step of assessment of data quality, which was accomplished by calculating the balance of positive and negative ions. Water fulfils the principle of electroneutrality and is therefore always uncharged. The level of error was calculated by using the following formula [12]:

- $\quad$ Error of ion balance $=((\Sigma$ cations $-\Sigma$ anions $) /(\Sigma$ cations $+\Sigma$ anions $)) * 100$

An error of up to $\pm 5 \%$ was considered as tolerable. The results of chemical analyses were then displayed through a Piper diagram.

Since water from wells and seasonal streams is currently used for human consumption, the chemical results were compared with the limits established by the regulations in force in South Sudan and the WHO regulations to provide information on the quality of water in the study area. More specifically, the following regulations were considered:

- World Health Organization (WHO) guidelines [13];

- Maximum permissible limit for drinking water quality in South Sudan.

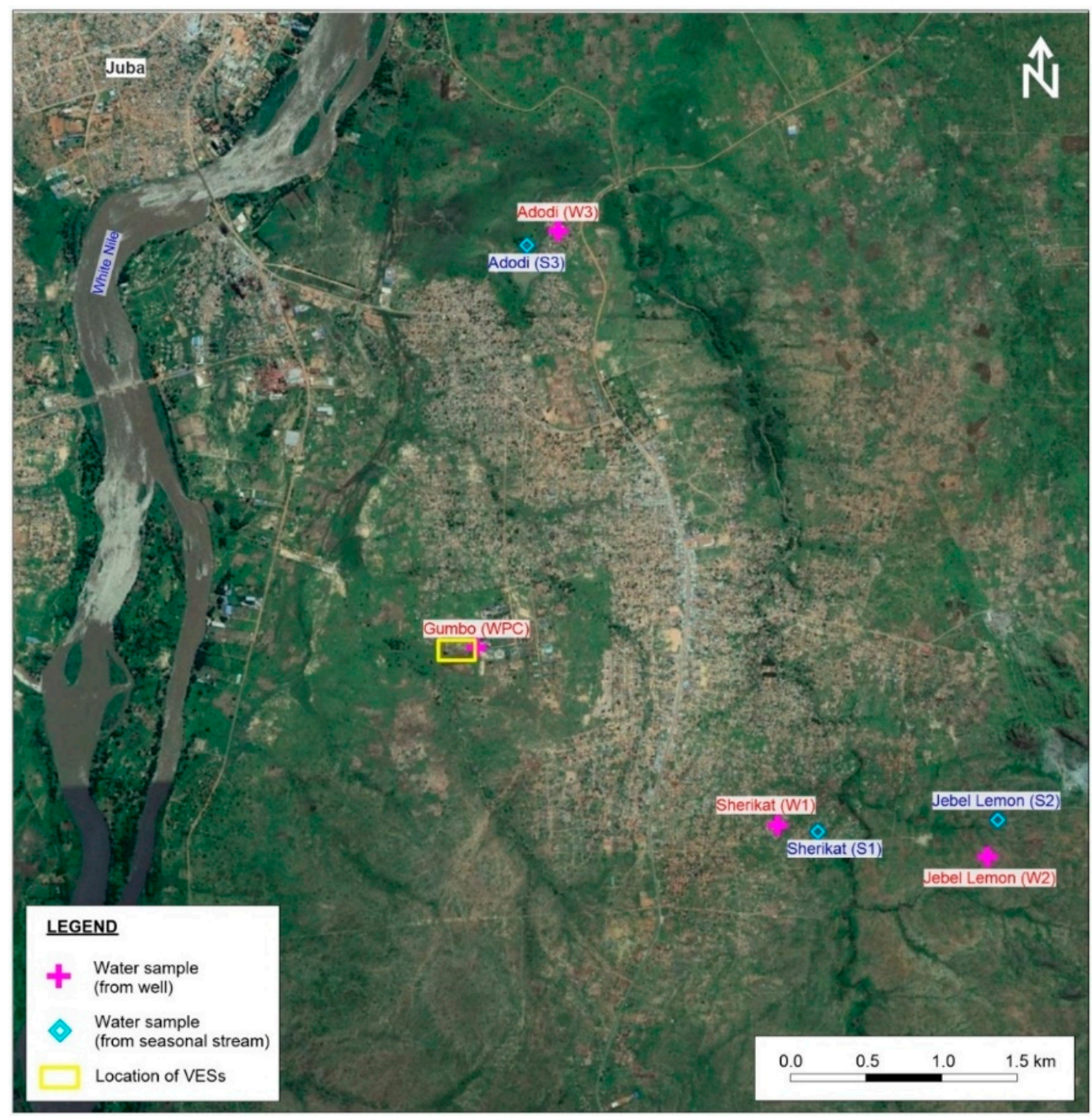

Figure 2. Location of the water samples taken for hydrochemical analyses (wells and seasonal streams) and vertical electrical soundings (VESs). 


\section{State-of-the-Art Knowledge in the Study Area}

The state-of-the-art geological and hydrogeological knowledge in South Sudan only includes general studies, at the regional or even national scale. The purpose of this review is to collect of all the available information, creating a solid framework on which setting up a more detailed local-scale dataset proposed in this study.

\subsection{Climate and Vegetation}

The average altitude of South Sudan is $470 \mathrm{~m}$ above sea level, with a gentle slope to the north. In general, the terrain is mainly plain with thick equatorial vegetation and savannah grasslands, and the climate is equatorial. As regards to the annual distribution of precipitation, the rainfall over the River Nile basin is characterized by highly uneven seasonal and spatial distribution. Most of the basins show only one rainy season, typically in the summer months. Only the equatorial zone has two distinct rainy periods. The probability of occurrence and volume of precipitation generally declines moving northwards, with the arid regions in Egypt and the northern region of Sudan receiving insignificant annual rainfall [14]. The area of Juba (specific object of this study) is in a sector characterized by a total rainfall (average annual for the period 1960-1990) between 900 and 1200 millimeters (Figure 3).

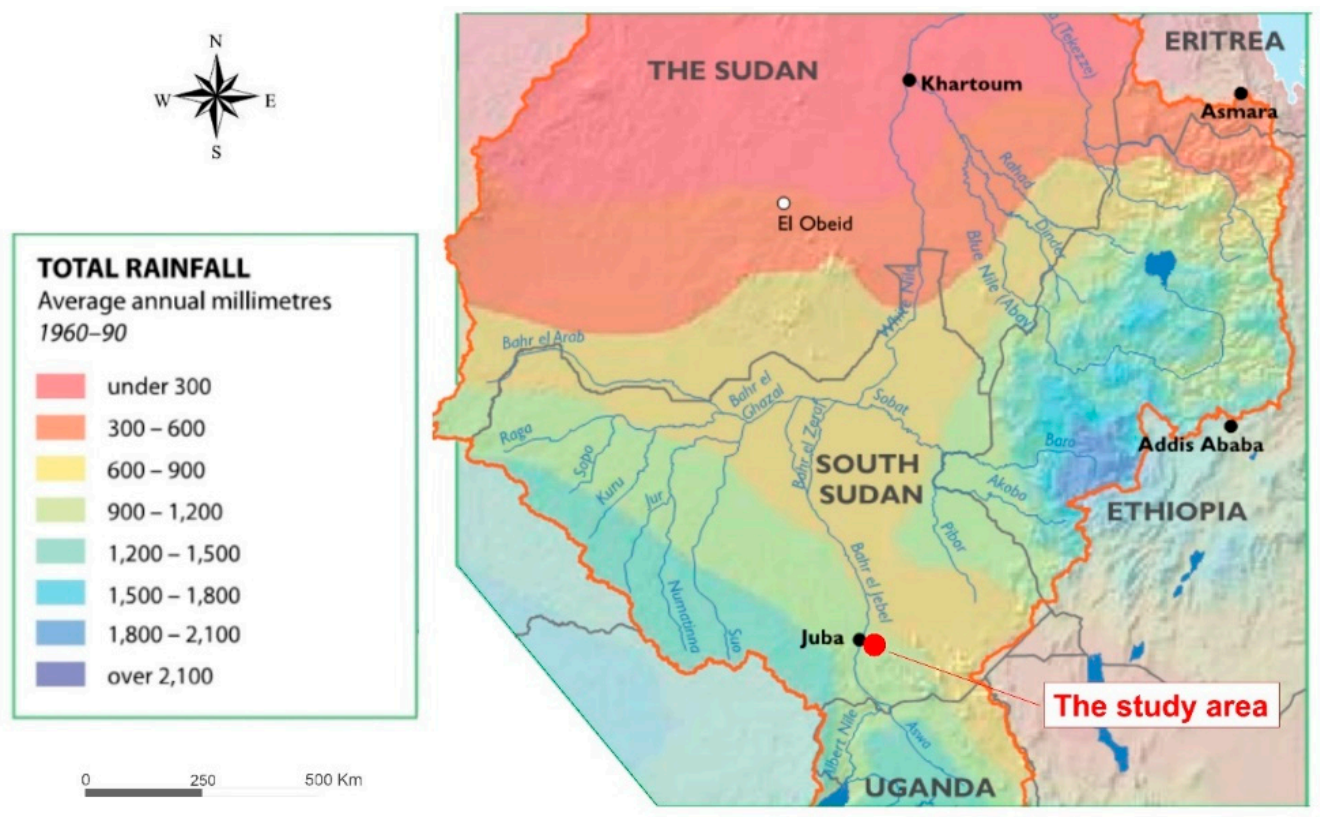

Figure 3. Average annual rainfall for the period 1960-1990 in South Sudan [14] and location of the study area. The orange line borders the River Nile Basin.

For a detailed description of the study area, data of the weather station in Juba [15] were collected and analyzed. The climate of Juba is tropical with average yearly temperature between 33.8 and $20.7^{\circ} \mathrm{C}$. Maximum temperature is during February-March, and minimum temperature is during December-January (Figure 4). The rainy season is from May to October. The dry season starts from November and ends in March and occurs particularly in January and February. Average yearly total rainfall is $974 \mathrm{~mm}$. (Figure 5). The highest number of rainy days occurs from April to October, whereas the lowest number of rainy days are reported in January. The average annual number of rainy days is 104 (Figure 6). 


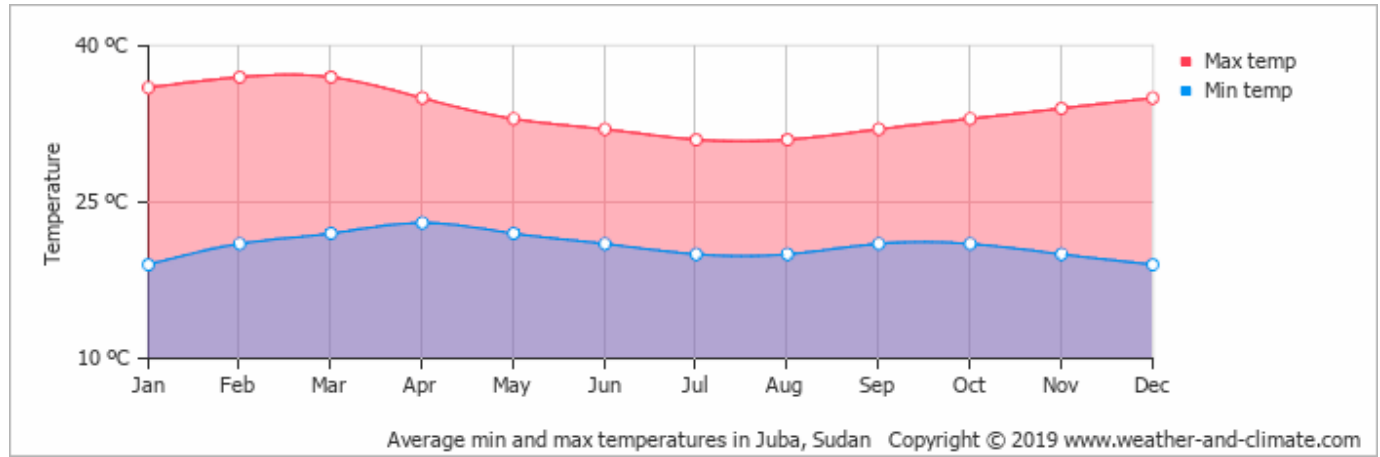

Figure 4. Monthly average minimum and maximum temperature of Juba [15].

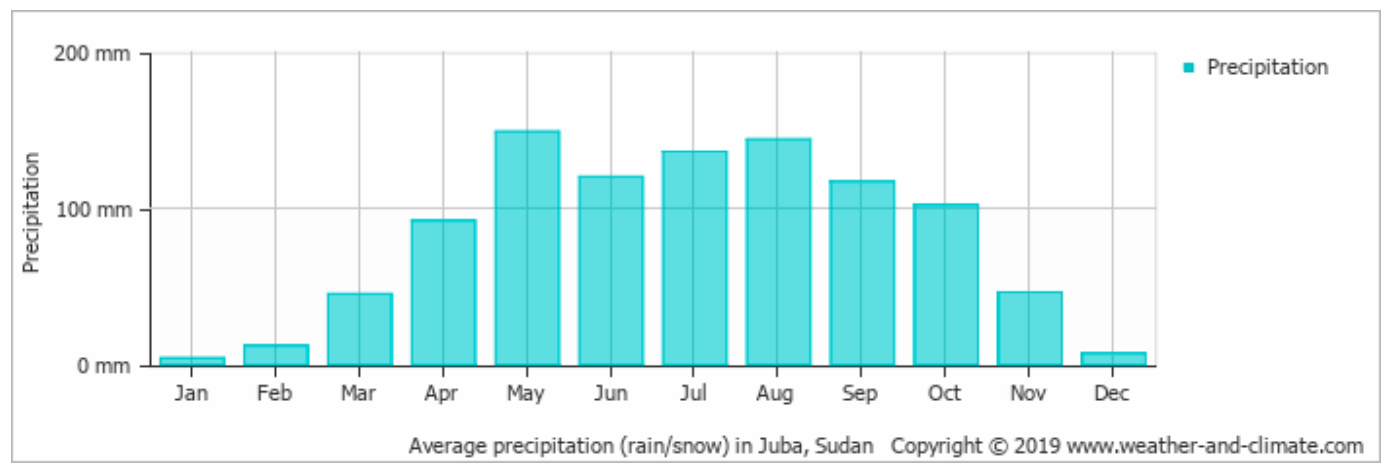

Figure 5. Monthly precipitation of Juba [15].

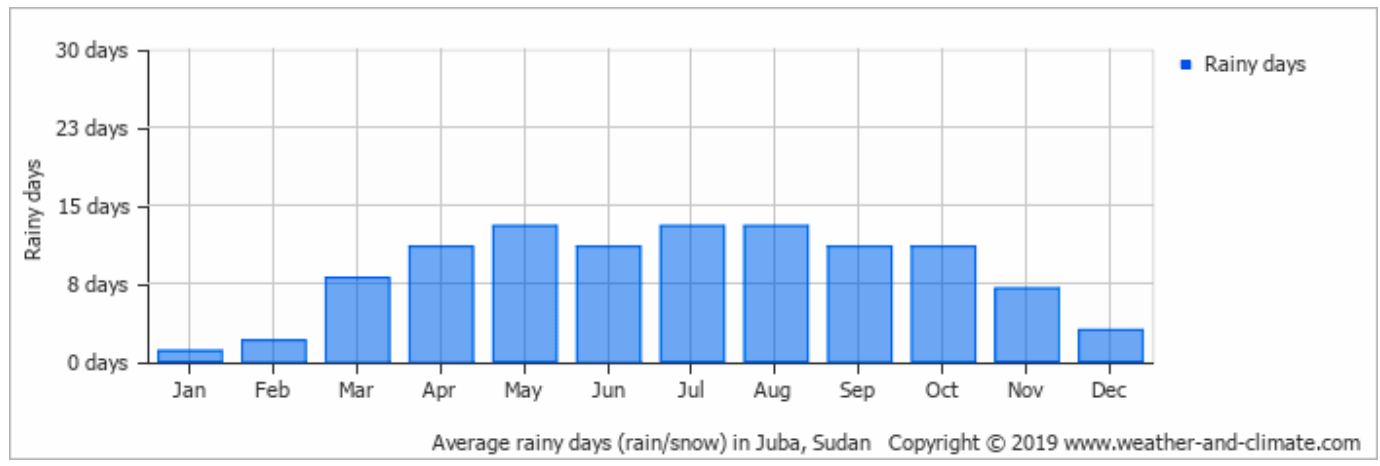

Figure 6. Average monthly rainy days over the year of Juba [15].

Across the Nile region, actual and potential evapotranspiration vary markedly [14]. Seasonal/ monthly variability of evapotranspiration is indeed a function of temperature, wind speed, relative humidity, solar radiation and biomass production. More specifically, the study area is located in a sector characterized by a potential evapotranspiration (average annual for the period 1960-1990) between 1600 and $1800 \mathrm{~mL}$ per year (Figure 7).

In the study area, the type of vegetation is biologically diverse, and it is not generally very dense. Examples of common trees are teak, shrubs and mango trees.

The rate of weathering is very high due to the combination of both high temperature and rainfall. This condition facilitates hydrolysis, oxidation and reduction and physical types of weathering such as the action of the plant's roots. 


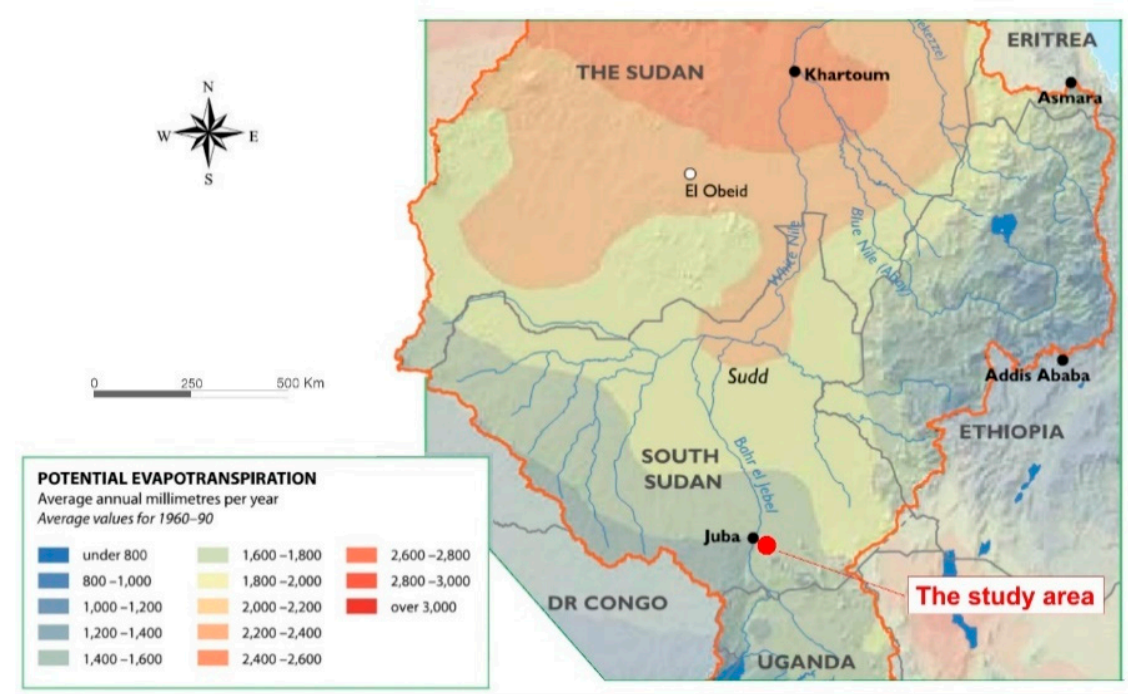

Figure 7. Average annual potential evapotranspiration for the period 1960-1990 [14] and location of the study area. The orange line borders the River Nile Basin.

\subsection{Geological Setting}

The geological setting of South Sudan comprises three main geological frameworks [16-18]:

- an extensive metamorphic basement complex and spatially associated granitic and basaltic intrusions;

- volcanic rifts;

- a widespread Tertiary-Quaternary cover sequence, mainly comprising poorly consolidated sands, clays and lateritic soils.

The basement complex is dominated by Proterozoic rocks of medium to high metamorphic grade, with isolated areas of probably older higher-grade granulitic rocks. In broad terms, the Proterozoic metamorphic basement comprises three main units: (i) variably banded and foliated granitic gneiss and migmatites (basement complex, dominantly banded magmatic gneiss in Figure 8), (ii) biotite-amphibole schist/amphibolites and (iii) calcareous meta-sediments and quartz meta-sediments (basement complex, dominantly schists and metasediments in Figure 8).

The crystalline basement complex hosts the majority of mineral occurrences. However, the recorded mineral presence is limited, because the country lacks a significant mineral resource evaluation.

Effusive basic volcanic rocks, mainly basaltic lava and tuffs, are found in the south-eastern part of the country (Rocks volcanics, mainly basalts in Figure 8 ) and are related to the activity of the East African Rift system.

The Neogene sequence comprises unconsolidated sands, gravels, clay sands and clays (Umm Rwaba Formation in Figure 8) characterized by rapid facies changes. Conditions of deposition of the Umm Rwaba formation are fluvial and lacustrine, with sediments laid down in a series of land deltas similar to those existing in present day South Sudan. The age of sediments is considered to range from Tertiary to Quaternary [19]. This formation hosts most of the ongoing oil exploration activities, and numerous holes/wells were drilled through the cover into the underlying basins. According to oil exploration data from Central and Southern Sudan, the maximum drilled thickness of the Umm Rwaba Formation is higher than $4600 \mathrm{~m}$. According to geophysical data, the maximum recorded thickness is higher than $8200 \mathrm{~m}$ in some places [16].

Extensive alluvial deposits underlie the flood plain of the Nile and many of its tributaries within the study area and toward the north of Juba. 


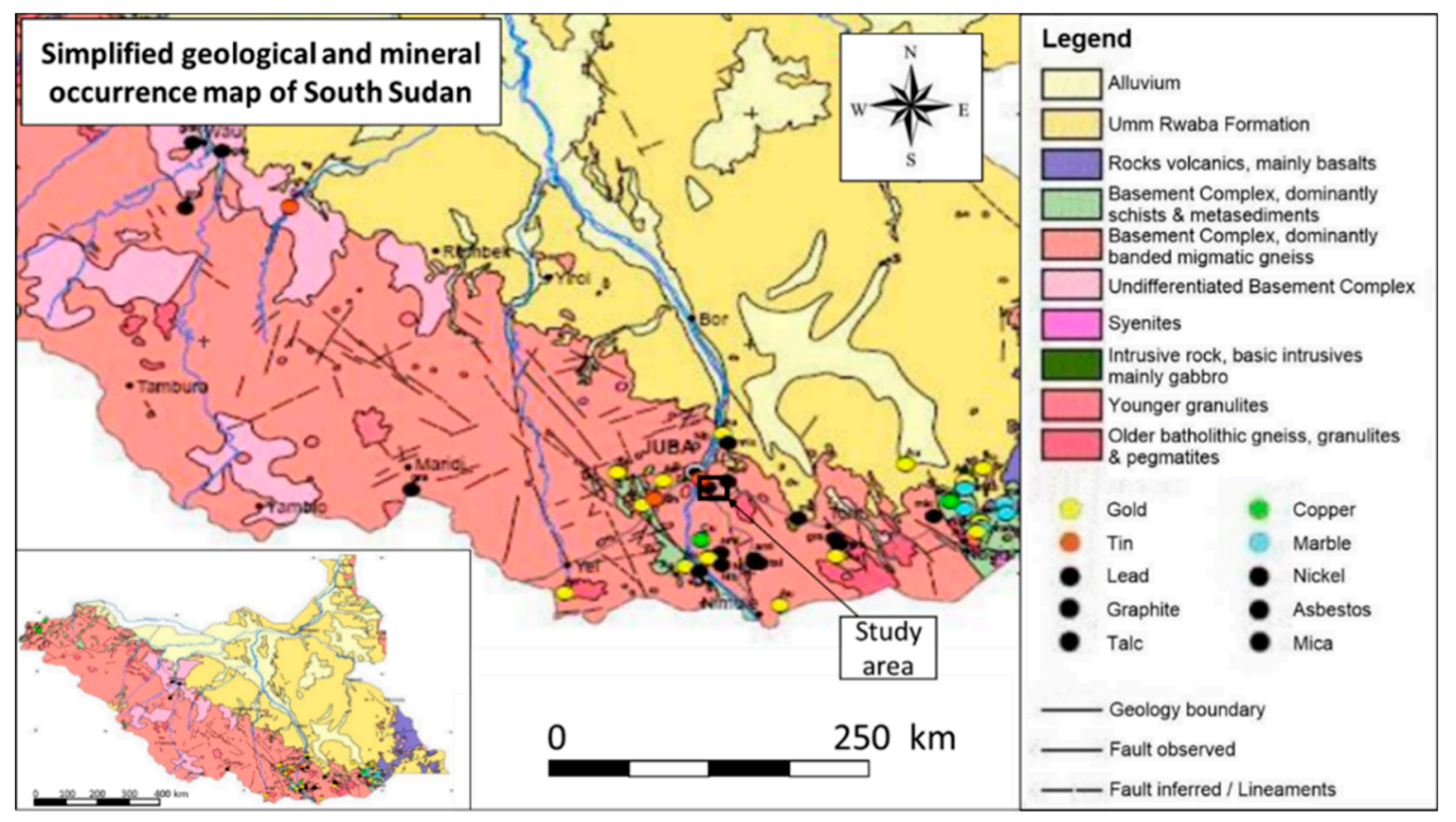

Figure 8. Map of the geology and mineral deposits of South Sudan [20] and location of the study area.

The Juba area is generally underlain by metamorphic rocks of the basement complex. The basement complex is overlain unconformably by alluvial and surficial deposits that vary in thickness from one location to another. In detail, the basement complex of Juba is composed of gneiss that ranges from medium to high grade metamorphism. Both banded and unbanded gneiss occurs in the area; different types such as augen gneiss, grey gneiss, etc., are present. The gneiss is intruded by several doleritic, gabbroic and granitic intrusions that occur as plutons, or doleritic, gabbroic dikes with east-west trending. The rocks in the study area are mildly deformed. The geological structures consist of both ductile structures, which include folds, foliation and crenulation cleavage, and structures with joints and faults.

Effects of weathering, due to the tropical climate of the area, can be seen in the change of surface color (usually dark or reddish brown) of most rocks, exfoliations and other types of physical weathering.

Close to the Nile River and its tributaries, the geology of the area is dominated by recent alluvium, terraces, deltas and swamp deposits.

\subsection{Hydrogeological Setting}

As shown in Figure 9, three different hydrogeological sectors may be identified in South Sudan, based on the structure of aquifers and on the recharge rate [14,21]:

- Major aquifers: The northern part of the state, on the border with Sudan, and the eastern part, on the border with Ethiopia. In these sectors, large and rather uniform groundwater basins are present, usually in large sedimentary basins, that may offer good conditions for groundwater exploitation;

- Local and shallow aquifers: Southern and western parts of the state, bordering Congo, Uganda and Central African Republic. These areas are characterized by limited groundwater resources in local and shallow aquifers;

- Complex hydrogeological structure: A small area in the south-eastern part of the state. Complex hydrogeological structures are found in heterogeneous folded or faulted regions, where highly productive aquifers are found in close proximity to areas without significant aquifers. 


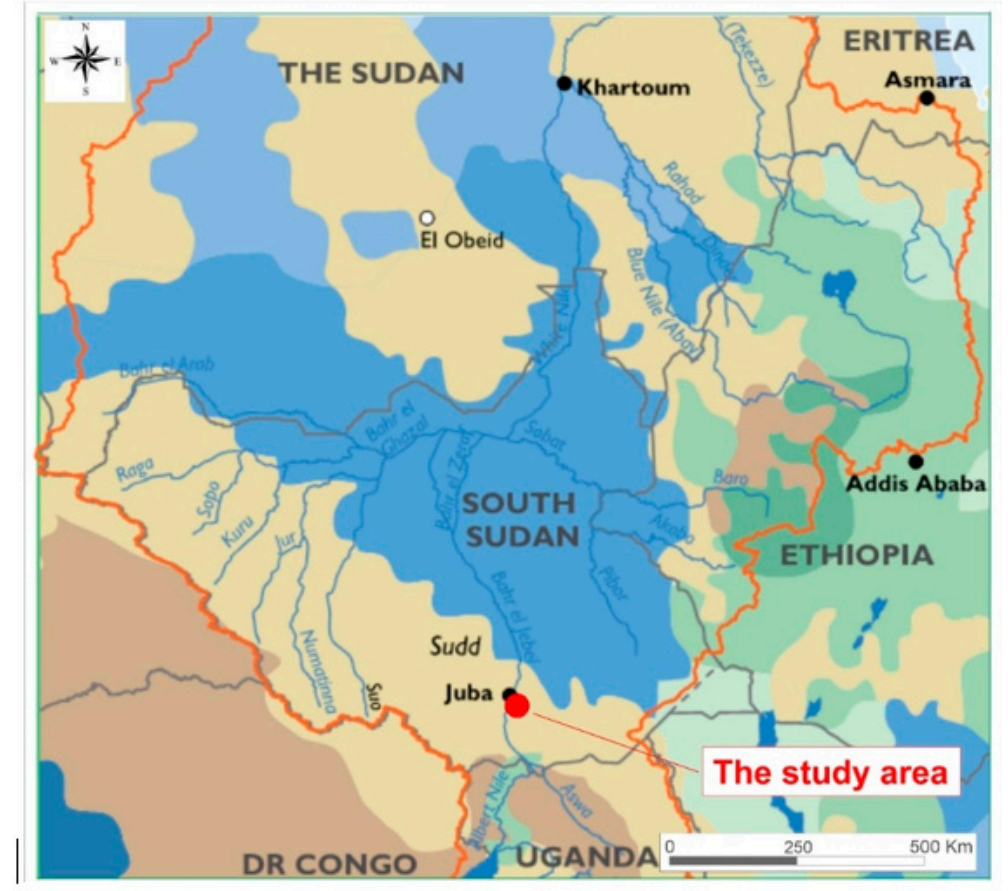

Structure and recharge rate, millimetres per year

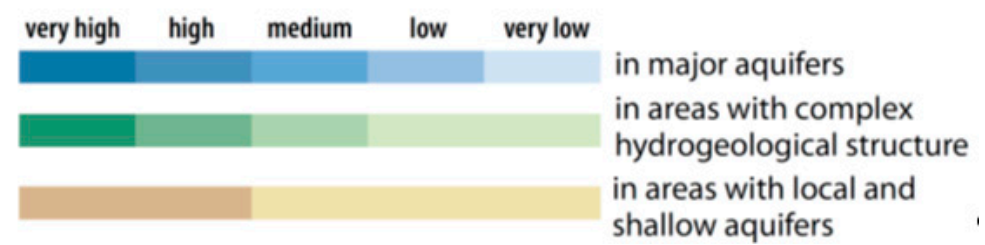

Figure 9. Sketch of the structure and recharge rate of the aquifers [14]. The orange line borders the River Nile Basin. The red circle indicates the study area.

The study area is located in a sector with local and shallow aquifers; the groundwater recharge rate is between medium and very low.

The shallow aquifers are usually located in the overburden or in a fractured upper part of the bedrock. The recharge of shallow aquifers is generally dependent on the size of the catchment area and the lithological character of the overburden.

In the study area, the cover sequence may contain a phreatic aquifer if constituted by coarse deposits (gravel, sand, pebble) of a large thickness. Groundwater in the basement formations generally occurs in the weathered (overburden) and fractured rocks. Weathered rocks, indeed, may have a good transmissivity and storage. However, the best aquifers are generally found at the contact zone between the overburden and the rocks. This zone has fewer secondary clay minerals, resulting in a higher transmissivity. Lastly, the highest yielding aquifers can be expected in the fractured bedrock. Boreholes are usually drilled into the fractured bedrock where the permeability is high and where the storage can be provided by the overburden. Fractured aquifers may be recharged through a connected system of fractured zones.

The hydrography of the study area consists of the Nile River and several other streams connected to the Nile River. 


\section{Results of the On-Site Survey}

\subsection{Lithostratigraphic Reconstruction}

The analysis of the stratigraphic logs of the four new drilled wells (Figure 10) highlighted the presence of a clayey and sandy soil on the surface, with a thickness between 1 and $8 \mathrm{~m}$, followed in depth by an alternation of non-fractured granite layers and altered wet granite or fractured granite.

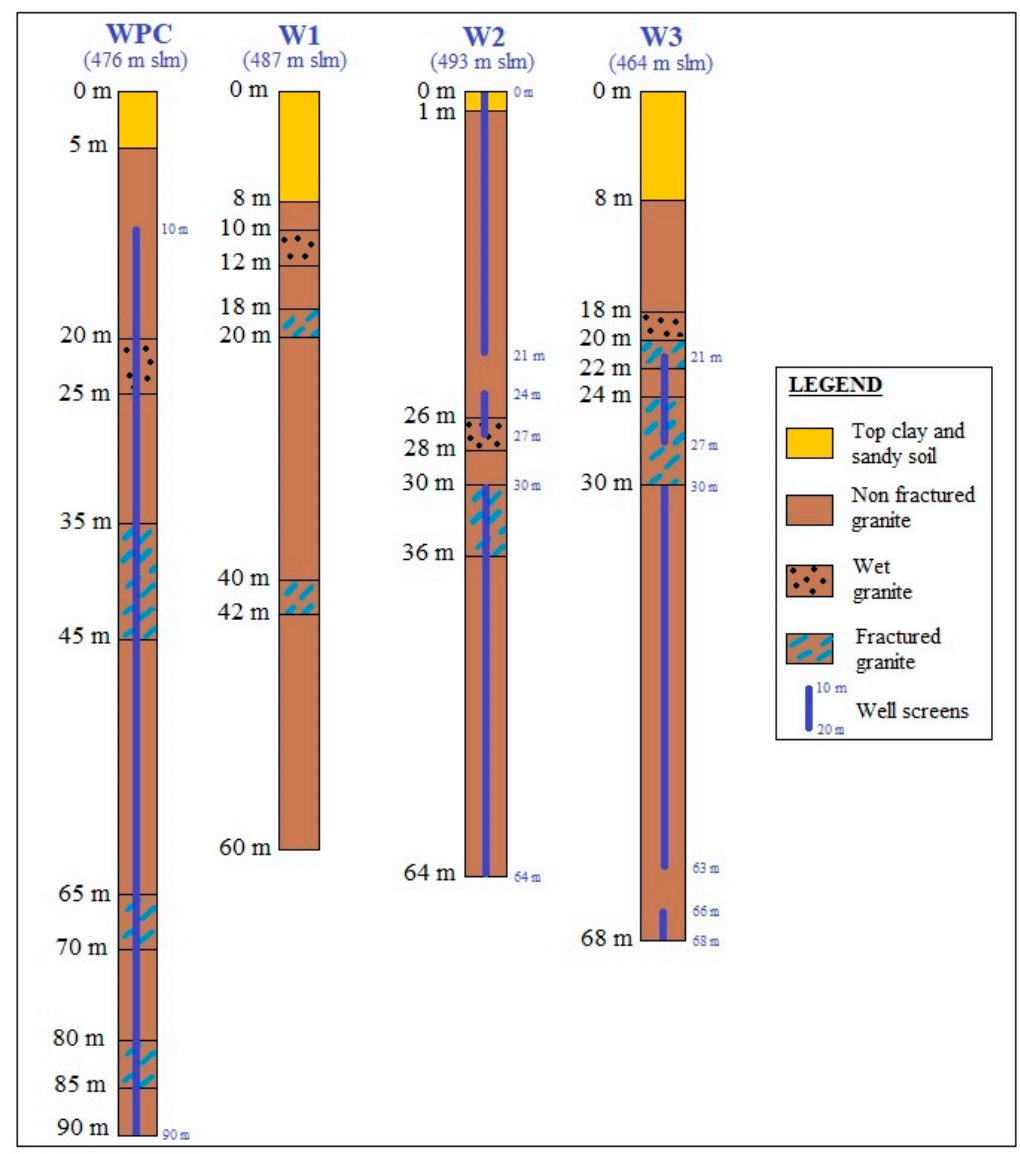

Figure 10. Stratigraphic logs of four new wells (not to scale).

The wet granite has a thickness of 2 to $5 \mathrm{~m}$ and is located at a depth ranging between 10 and $20 \mathrm{~m}$. The first level of fractured granite has a variable thickness of 2 to $10 \mathrm{~m}$ and depth ranging between 18 and $35 \mathrm{~m}$. The second level of fractured granite has thickness of 2 to $6 \mathrm{~m}$ and depth ranging between 24 and $65 \mathrm{~m}$.

The screens are mainly positioned in the granitic basement along the entire depth of the wells, with the exception of well W2, which also catches water from the overburden, suggesting the role of both the overburden and bedrock as local aquifers.

The two VESs performed near to the WPC well enabled the identification of layers with homogeneous resistivity (Figure 11). VES1 has slightly lower apparent resistivity values than VES2, but their results are coherent. More specifically, they show the presence in the subsoil of three main layers with different thicknesses and apparent resistivity. In general, the data show the existence of a first layer, with a thickness of about $2 \mathrm{~m}$, characterized by intermediate resistivity that is followed in depth by a second layer with low resistivity, up to about 20-25 $\mathrm{m}$. The resistivity profile ends with a third layer with high resistivity and up to $50 \mathrm{~m}$ of depth. 

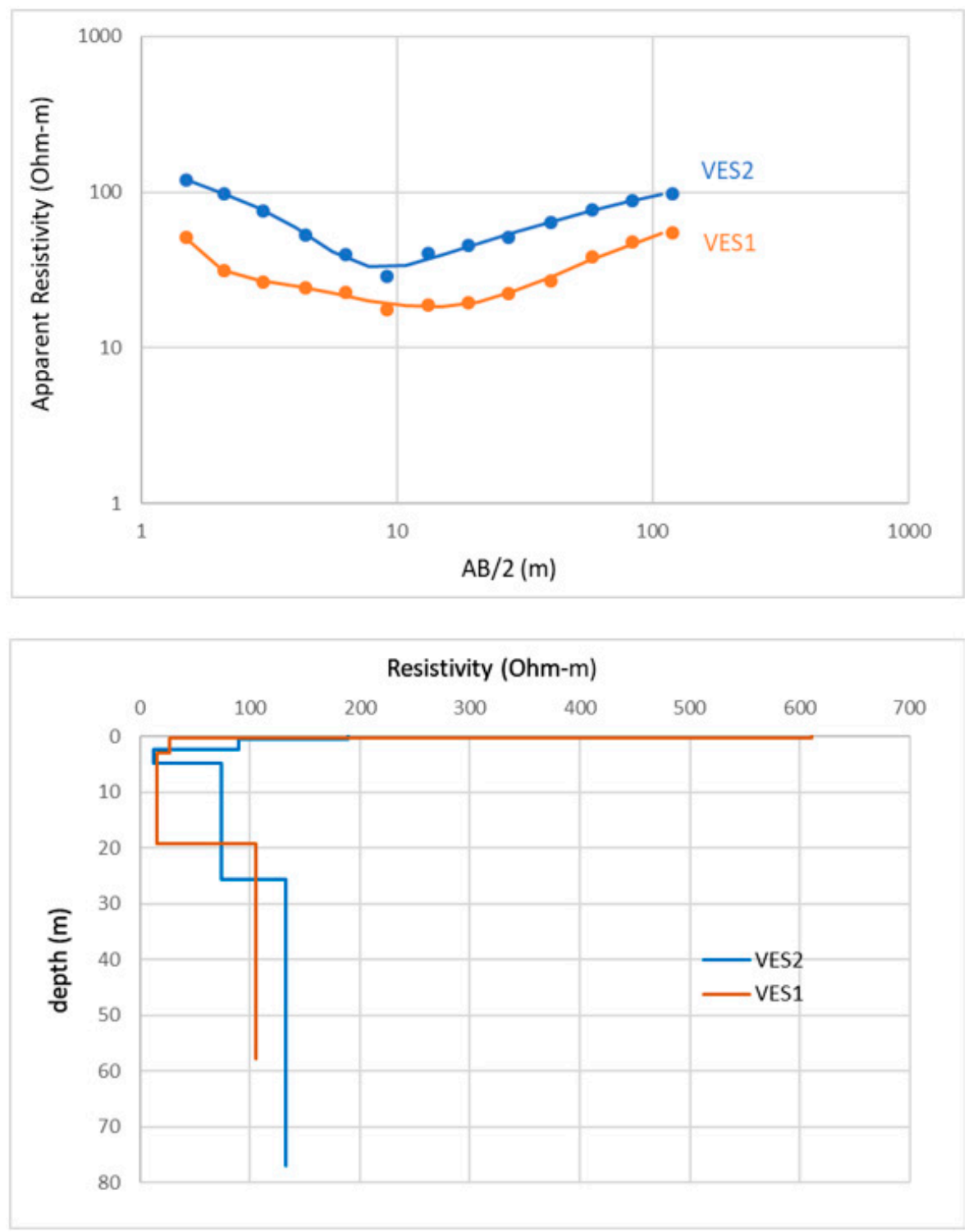

Figure 11. Graph with the results of the two VESs and their elaboration.

\subsection{Hydrogeological Reconstruction}

Table 1 reports the position, depth and diameter of the wells and the respective water level measurements. The depth of water table ranges between 8.0 and $24.3 \mathrm{~m}$ b.g.l. (i.e., piezometric level between 456.0 and $468.7 \mathrm{~m}$ a.s.l). The direction of groundwater flow is predominantly SSE-NNW, in the direction of the White Nile, which serves as a drainage axis of the entire surrounding plain sector.

Table 1. Data used for the piezometric reconstruction (spring-summer 2018).

\begin{tabular}{cccccccc}
\hline Location & $\begin{array}{c}\text { Id. } \\
\text { Code }\end{array}$ & $\begin{array}{c}\text { Latitude } \\
\mathbf{( N )}\end{array}$ & $\begin{array}{c}\text { Longitude } \\
\mathbf{( E )}\end{array}$ & $\begin{array}{c}\text { Well } \\
\text { Depth }(\mathbf{m})\end{array}$ & $\begin{array}{c}\text { Well Diameter } \\
(\mathbf{m})\end{array}$ & $\begin{array}{c}\text { Depth to Water Table from } \\
\text { Ground Level (m b.g.1.) }\end{array}$ & $\begin{array}{c}\text { Water Table Level } \\
(\mathbf{m} \text { a.s.l.) }\end{array}$ \\
\hline Sherikat & W1 & 4.7849722 & 31.6433055 & 60 & 0.1016 & 12.0 & 475.0 \\
Jebel Lemon & W2 & 4.783132 & 31.6562968 & 64 & 0.1016 & 24.3 \\
Adodi & W3 & 4.8202146 & 31.6301272 & 68 & 0.1016 & 8.0 & 468.7 \\
Gumbo & WPC & 4.7953400 & 31.6249200 & 90 & 0.1524 & 8.0 & 456.0 \\
\hline
\end{tabular}

Figure 12 reports the resulting water table map. Since the piezometric reconstruction is based on only four wells, the map only indicates the main direction of groundwater flow. 


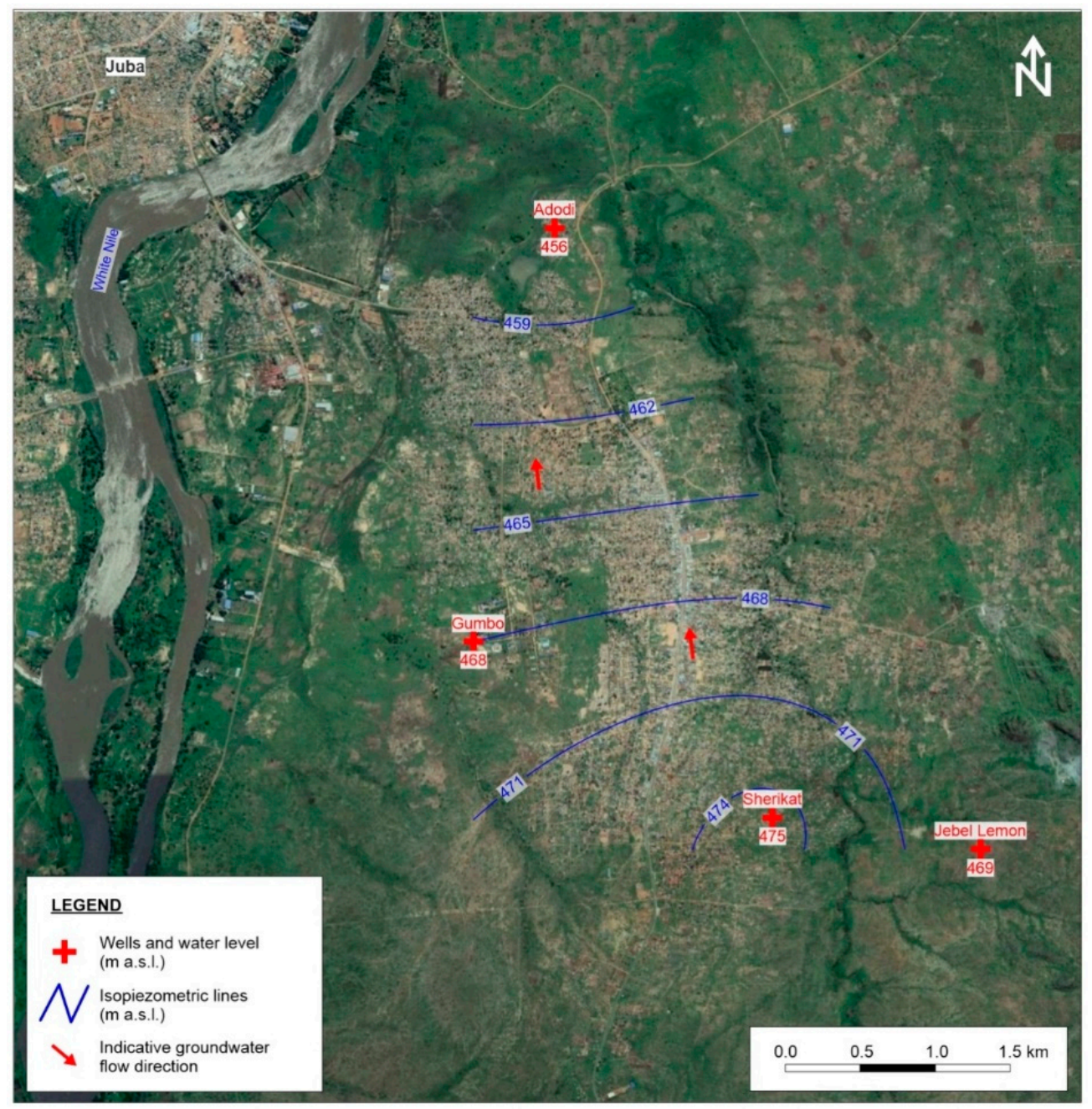

Figure 12. Water table map for spring-summer 2018. Due to the scarce data, the map gives indicative information about the hydraulic gradient and groundwater flow direction.

\subsection{Hydrochemical Analyses}

Table 2 reports the results of the water chemical analyses. The error of ion balance was always less than $\pm 5 \%$, and consequently it was considered tolerable. Table 2 also reports the comparison with the limits established by the regulations in force in South Sudan and the WHO regulations, providing information on the quality of water for human consumption in the study area.

Results show that both the content in individual elements and the total mineralization are very variable, depending on the analyzed sample. In general, however, surface water from seasonal streams has lower electrolytic conductivity and chloride levels.

The WPC groundwater sample, taken in 2017, shows different chemical features when compared to groundwater samples taken in W1, W2 and W3 wells in 2018. The latter, indeed, have higher heavy metal content. This difference is probably due to the different positions of screens in the wells and thus to the different sampled aquifers.

The limit value of total hardness of the South Sudan regulation $(200 \mathrm{mg} / \mathrm{L})$ is only respected in samples W3, W2 and S2, whereas the W1, S1 and S3 exceed it.

The single ions exceeding the suggested limits by the $\mathrm{WHO}$ and national regulation that may assume negative effects for human health in the long term and negative consequences for the soil in case of agricultural use are chromium (according to WHO limits) and sodium, fluorides and manganese (with regards to the South Sudan legislation limits). 
Table 2. Results of chemical analyses and comparison with permissible limits for the South Sudan legislation and WHO guidelines for drinking water quality. The parameters exceeding the permissible limits for the South Sudan legislation are in light blue; those that exceed the WHO guidelines for drinking water quality are in red (N.M. = not measured).

\begin{tabular}{|c|c|c|c|c|c|c|c|c|c|c|}
\hline \multicolumn{4}{|c|}{$\begin{array}{c}\text { Sample } \\
\text { Date }\end{array}$} & \multirow{2}{*}{$\begin{array}{l}\text { WPC "Gumbo" } \\
\text { August 2017 } \\
\text { Value }\end{array}$} & \multirow{2}{*}{$\begin{array}{l}\text { W1 "Sherikat" } \\
\text { July } 2018 \\
\text { Value }\end{array}$} & \multirow{2}{*}{$\begin{array}{l}\text { W2 "Jebel Lemon" } \\
\text { July } 2018 \\
\text { Value }\end{array}$} & \multirow{2}{*}{$\begin{array}{l}\text { W3 "Adodi" } \\
\text { July 2018 } \\
\text { Value }\end{array}$} & \multirow{2}{*}{$\begin{array}{l}\text { S1 "Sherikat" } \\
\text { July } 2018 \\
\text { Value }\end{array}$} & \multirow{2}{*}{$\begin{array}{l}\text { S2 "Jebel Lemon" } \\
\text { July } 2018 \\
\text { Value }\end{array}$} & \multirow{2}{*}{$\begin{array}{c}\text { S3 “Adodi" } \\
\text { July } 2018 \\
\text { Value }\end{array}$} \\
\hline Parameter & U.M. & $\begin{array}{l}\text { Limit Values } \\
\text { (South Sudan) }\end{array}$ & $\begin{array}{l}\text { Limit Values } \\
\text { (WHO 2011) }\end{array}$ & & & & & & & \\
\hline $\mathrm{pH}$ & $\mathrm{pH}$ & $6.5-9.5$ & & N.M. & 7.71 & 7.81 & 8.09 & 7.30 & 7.43 & 7.71 \\
\hline Total suspended solids & $\mathrm{mg} / \mathrm{L}$ & & & N.M. & 25.0 & 29.0 & 30.0 & 23.0 & 27.0 & 25.0 \\
\hline Electrolytic Conductivity $\left(20^{\circ} \mathrm{C}\right)$ & $\mu \mathrm{S} / \mathrm{cm}$ & 1500 & & N.M. & 1138 & 553 & 1248 & 221 & 397 & 788 \\
\hline Aluminum & $\mu \mathrm{g} / \mathrm{L}$ & & & 1.1 & $<1.0$ & $<1.0$ & $<1.0$ & $<1.0$ & $<1.0$ & $<1.0$ \\
\hline Antimony & $\mu \mathrm{g} / \mathrm{L}$ & & 20 & $<0.5$ & $<0.5$ & $<0.5$ & $<0.5$ & 3.6 & $<0.5$ & $<0.5$ \\
\hline Silver & $\mu \mathrm{g} / \mathrm{L}$ & & & $<1.0$ & $<1.0$ & $<1.0$ & $<1.0$ & $<1.0$ & $<1.0$ & $<1.0$ \\
\hline Arsenic & $\mu \mathrm{g} / \mathrm{L}$ & 50 & 10 & 4.8 & $<1.0$ & $<1.0$ & $<1.0$ & $<1.0$ & $<1.0$ & $<1.0$ \\
\hline Beryllium & $\mu g / L$ & & & $<0.1$ & $<0.1$ & $<0.1$ & $<0.1$ & $<0.1$ & $<0.1$ & $<0.1$ \\
\hline Cadmium & $\mu \mathrm{g} / \mathrm{L}$ & $3-5$ & 3 & $<0.2$ & $<0.2$ & $<0.2$ & $<0.2$ & $<0.2$ & $<0.2$ & $<0.2$ \\
\hline Cobalt & $\mu \mathrm{g} / \mathrm{L}$ & & & $<1.0$ & $<1.0$ & $<1.0$ & $<1.0$ & $<1.0$ & $<1.0$ & $<1.0$ \\
\hline Total Chromium & $\mu \mathrm{g} / \mathrm{L}$ & & 50 & $<1.0$ & 55.1 & 59.8 & 38.5 & 11.1 & 8.8 & 63.5 \\
\hline Chromium VI & $\mu \mathrm{g} / \mathrm{L}$ & & & $<3.0$ & $<3.0$ & $<3.0$ & $<3.0$ & $<3.0$ & $<3.0$ & $<3.0$ \\
\hline Iron & $\mu \mathrm{g} / \mathrm{L}$ & 500 & & $<1.0$ & 192 & 206 & 136 & 43.7 & 35.1 & 219 \\
\hline Mercury & $\mu g / L$ & & 6 & & 0.2 & 0.2 & 0.5 & 0.1 & 1.3 & $<0.1$ \\
\hline Nickel & $\mu \mathrm{g} / \mathrm{L}$ & & 70 & $<1.0$ & 58.6 & 64.6 & 42.5 & 14.2 & 11.0 & 60.8 \\
\hline Lead & $\mu \mathrm{g} / \mathrm{L}$ & & 10 & $<1.0$ & 3.1 & 1.2 & 1.5 & $<1.0$ & $<1.0$ & $<1.0$ \\
\hline Copper & $\mu \mathrm{g} / \mathrm{L}$ & 1500 & 2000 & $<1.0$ & 2.1 & 2.1 & 2.9 & 1.3 & 1.0 & 2.0 \\
\hline Selenium & $\mu \mathrm{g} / \mathrm{L}$ & & 40 & $<1.0$ & $<1.0$ & $<1.0$ & $<1.0$ & $<1.0$ & $<1.0$ & $<1.0$ \\
\hline Manganese & $\mu \mathrm{g} / \mathrm{L}$ & 400 & & $<1.0$ & 55.9 & 469 & 6.3 & 2.0 & 1.6 & 8.9 \\
\hline Thallium & $\mu \mathrm{g} / \mathrm{L}$ & & & $<0.2$ & $<0.2$ & $<0.2$ & $<0.2$ & $<0.2$ & $<0.2$ & $<0.2$ \\
\hline Zinc & $\mu \mathrm{g} / \mathrm{L}$ & 3000 & & 31.6 & 1183 & 418 & 622 & 37.7 & 46.1 & 182 \\
\hline Potassium & $\mathrm{mg} / \mathrm{L}$ & $25-50$ & & 14.7 & 12.5 & 11.2 & 4.46 & 5.01 & 3.91 & 10.9 \\
\hline Calcium & $\mathrm{mg} / \mathrm{L}$ & $80-150$ & & 109 & 85.9 & 52.5 & 10.7 & 24.9 & 46.7 & 68.2 \\
\hline Sodium & $\mathrm{mg} / \mathrm{L}$ & 100 & & 115 & 102 & 98.8 & 103 & 29.2 & 62.8 & 103 \\
\hline Magnesium & $\mathrm{mg} / \mathrm{L}$ & & & 29.8 & 45.7 & 15.1 & 6.03 & 6.75 & 9.32 & 26.1 \\
\hline Boron & $\mu \mathrm{g} / \mathrm{L}$ & & 2400 & $<15.0$ & 53.6 & 40.6 & 43.3 & 42.5 & 37.0 & 50.3 \\
\hline Titanium & $\mu \mathrm{g} / \mathrm{L}$ & & & $<1.0$ & N.M. & N.M. & N.M. & N.M. & N.M. & N.M. \\
\hline Total phosphorus $(\mathrm{P})$ & $\mu \mathrm{g} / \mathrm{L}$ & & & 32.9 & N.M. & N.M. & N.M. & N.M. & N.M. & N.M. \\
\hline Molybdenum & $\mu \mathrm{g} / \mathrm{L}$ & & & $<1.0$ & N.M. & N.M. & N.M. & N.M. & N.M. & N.M. \\
\hline Tin & $\mu g / L$ & & & $<1.0$ & N.M. & N.M. & N.M. & N.M. & N.M. & N.M. \\
\hline Fluorides & $\mu \mathrm{g} / \mathrm{L}$ & 1000 & 1500 & 822 & 1139 & 1342 & 1047 & 431 & 1300 & 1430 \\
\hline Nitrite (NO2) & $\mu \mathrm{g} / \mathrm{L}$ & 500 & 3000 & & $<50$ & $<50$ & $<50$ & $\frac{10}{<50}$ & $<50$ & $<50$ \\
\hline Sulphates & $\mathrm{mg} / \mathrm{L}$ & 200 & & 9.62 & 99.9 & 0.68 & 36.5 & 1.29 & 2.64 & 36.1 \\
\hline Chlorides & $\mathrm{mg} / \mathrm{L}$ & 200 & & 17.1 & 69.8 & 2.32 & 54.0 & 2.73 & 10.9 & 38.0 \\
\hline Phosphates (PO4) & $\mathrm{mg} / \mathrm{L}$ & & & N.M. & $<0.10$ & $<0.10$ & 0.39 & 0.15 & $<0.10$ & $<0.10$ \\
\hline Bromides & $\mathrm{mg} / \mathrm{L}$ & & & N.M. & $<0.10$ & $<0.10$ & $<0.10$ & $<0.10$ & $<0.10$ & $<0.10$ \\
\hline Nitrates (NO3) & $\mathrm{mg} / \mathrm{L}$ & 30 & 50 & 4.9 & 0.4 & 0.4 & 0.4 & 0.4 & 1.4 & 25.1 \\
\hline Total Cyanides & $\mu \mathrm{g} / \mathrm{L}$ & & & N.M. & $<10$ & $<10$ & $<10$ & $<10$ & $<10$ & $<10$ \\
\hline Total Hardness & $\mathrm{F}^{\circ}$ & & & N.M. & 40.3 & 19.3 & 5.1 & 26.5 & 15.5 & 27.8 \\
\hline Total Hardness & $\mathrm{mg} / \mathrm{LCaCO} 3$ & 200 & & 394 & 403 & 193 & 51 & 265 & 155 & 278 \\
\hline $\mathrm{CO} 3-+\mathrm{HCO}_{-}-$ & $\mathrm{mg} / \mathrm{L}$ & & & 701.5 & 585.6 & 561.2 & 195.2 & 201.3 & 372.1 & 439.2 \\
\hline
\end{tabular}


The levels of sodium are usually higher in groundwater than in surface water. WPC, W1, W3 and S3 have sodium concentrations slightly higher than South Sudan limits.

Greater attention must be paid to fluoride, which presents medium-high concentrations (between 800 and $1400 \mu \mathrm{g} / \mathrm{L}$ ) in water samples W1, W2, W3, S2 and S3. High fluoride levels may cause damage to bones, kidneys and teeth.

Manganese is usually found in concentrations less than $10 \mu \mathrm{g} / \mathrm{L}$, with the exception of wells W1 $(55.9 \mu \mathrm{g} / \mathrm{L})$ and W2 $(469 \mu \mathrm{g} / \mathrm{L}$, greater than the South Sudan legislation limit).

The hexavalent form of Chromium, which is very toxic and carcinogenic to humans, is always less than $3 \mu \mathrm{g} / \mathrm{L}$. On the contrary, the trivalent form, that is not carcinogenic, is present in concentrations higher than the WHO limits for the samples W1, W2 and S3.

To clarify the distribution of parameters exceeding the permissible limits, Figure 13 reports the samples with a content higher than South Sudan national legislation and WHO guidelines, specifying the water concentration.

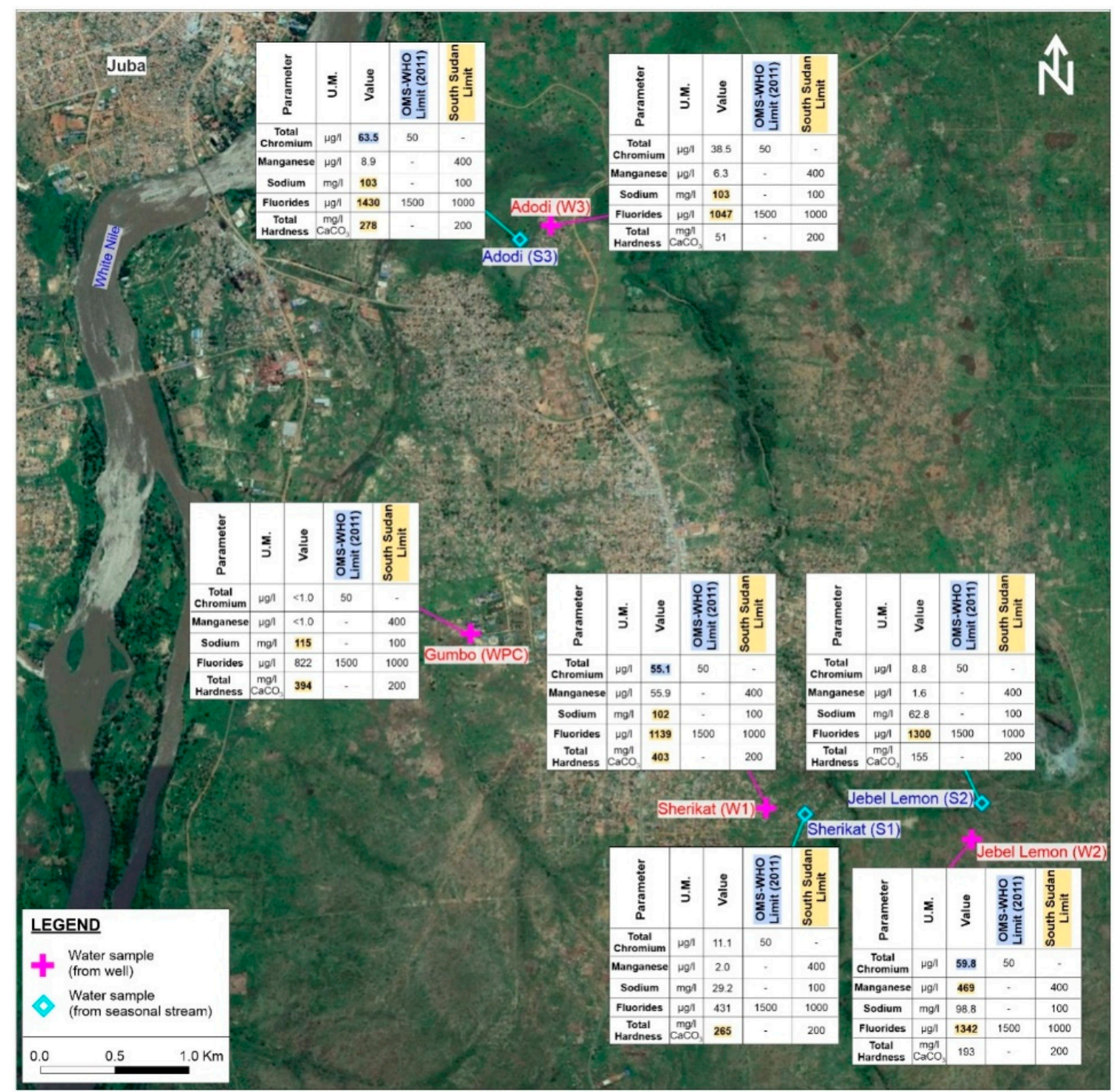

Figure 13. Map of the distribution of the chemical parameters exceeding the permissible limits for the South Sudan national legislation and WHO guidelines for drinking water quality. 


\section{Discussions}

The set of lithostratigraphic, hydrogeological and hydrochemical data collected with the on-site survey allowed a local framework for the distribution and the quality of the water resource to be defined.

The analysis of VES results and borehole logs coherently suggest the presence of a few meters of overburden (intermediate resistivity) followed by altered/fractured granite (low resistivity) up to $20 \mathrm{~m}$ depth and no fractured granite (higher resistivity) at a lower depth. Considering the depth of the wells and the reliability of information coming from direct geological investigation, the borehole logs suggest the alternation of fractured and non-fractured granite up to the end of the wells (60 to $90 \mathrm{~m}$ depth).

Based on this lithostratigraphic setting (overburden and igneous bedrock), Figure 14 proposes four possible hydrogeological scenarios. Data suggest the presence of local and shallow aquifers with medium to very low groundwater recharge rate. Phreatic aquifers are hosted in the coarse unconsolidated deposits or in the altered basement, whereas the local aquifers are associated with the fractured basement. The best aquifers are generally located at the contact zone between the overburden and the rocks and in the fractured rocks of the bedrock, which hosts the highest yielding aquifers.

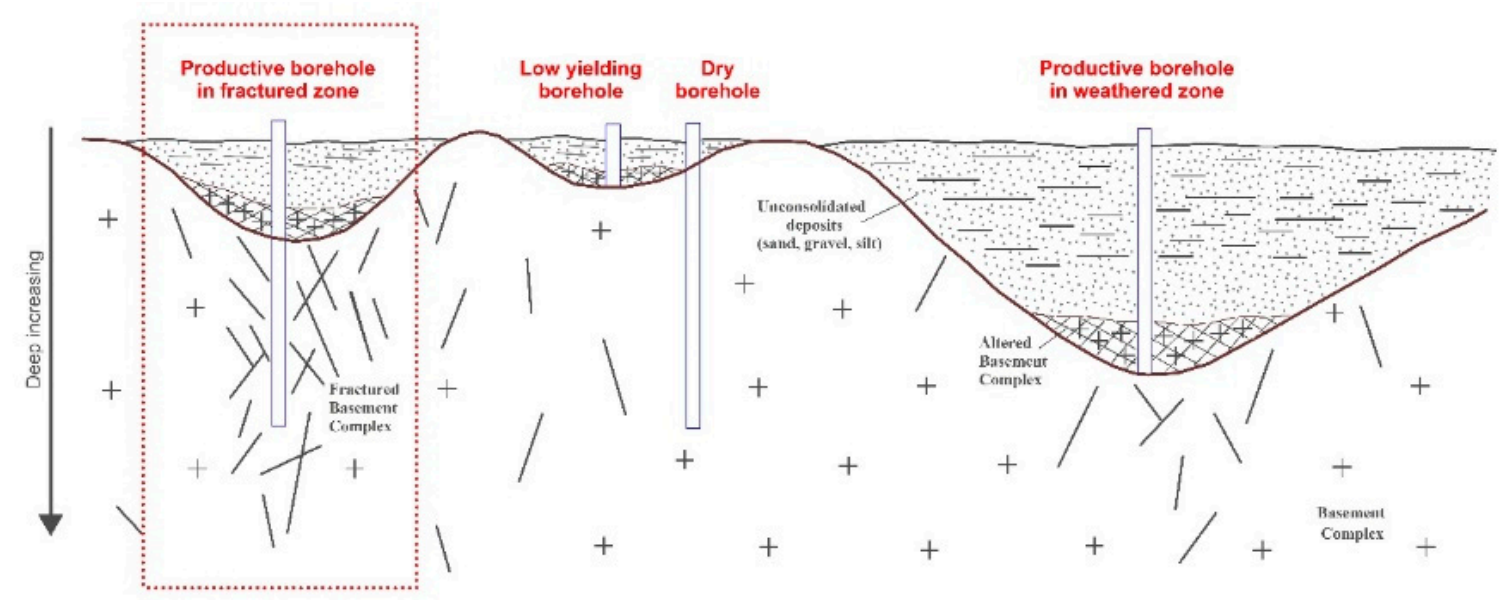

Figure 14. Possible scenarios for wells drilled in locations similar to the Gumbo area from a lithostratigraphic-hydrogeological point of view.

This conceptual model is coherent with the hydrogeological framework at the national scale retrieved from the available literature [14,21], which identifies the major aquifers in the northern and in the eastern parts of the state (i.e., on the borders with Sudan and Ethiopia), where the geological setting describes the presence of thick fluvial and lacustrine deposits. The southern and western parts of the region, where the Gumbo area is located, mainly consists of granite and other crystalline rocks, only creating the conditions for local and shallow aquifers. As a consequence of this general assessment, the report [22] describes a difference in the potential between the northern and eastern aquifers and the ones in the south and west wide areas of the country. The former are described as excellent aquifers, with high potential mainly depending on the depth and the good permeability properties of the deposits; the latter, being located in areas characterized by the presence of the basement complex, are described as low potential aquifers, of which yield of groundwater is only enough for rural or urban water supply.

In this hydrogeological framework, despite a general low expected productivity, the local conditions may allow water production to be optimized if the drilling is performed in accordance with the conditions defined as "Productive borehole in fractured zone" (Figure 14), where the boreholes are drilled both in the overburden and fractured bedrock and the latter is characterized by layers of high permeability due to alteration (altered basement complex) or fractures (fractured basement complex). The storage can be provided by the overburden. 
The hydrochemical characterization of surface and groundwater is a complete novelty in the panorama of available data on South Sudan. The results furnish the main chemical features of water of the area, normally used for human consumption, irrigation and livelihood.

The data registered a local exceeding of the suggested limits, with assumed possible negative effects for the human health in the long term and negative consequences for the soil in case of agricultural use, for chromium, sodium, fluorides, manganese and total hardness. In general, surface water, coming from seasonal streams, highlighted a lower water quality and scarcer and more ephemeral discharge. Indeed, even if it represents the most direct, cheapest and most easily obtained water resource for humans and animals, it shows higher vulnerability to biological and chemical pollution and is easy to contaminate by anthropic input. Hence, the best supply is represented by groundwater.

Even if the number of samples is very low, some considerations of the relationship between single parameters were made. Chlorides vs. sodium, sodium vs. electrolytic conductivity and chlorides vs. electrolytic conductivity graphs show in general good correlations for surface water (Figure 15).

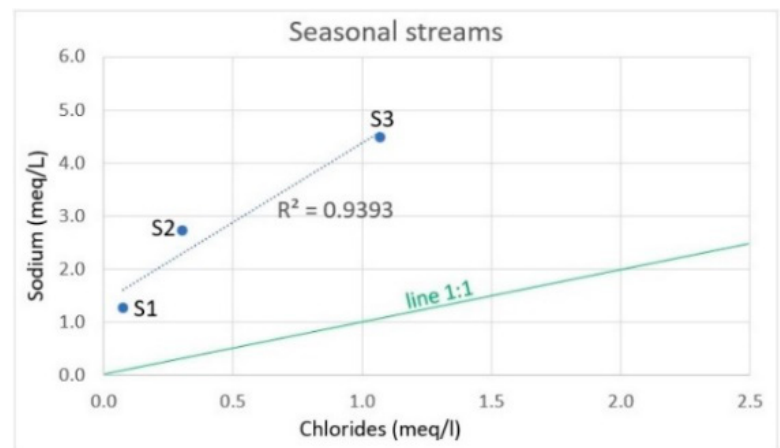

(a)

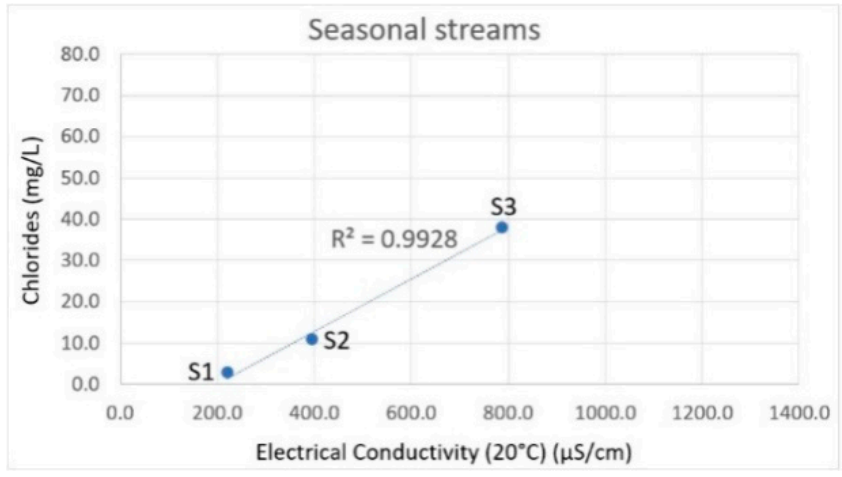

(b)

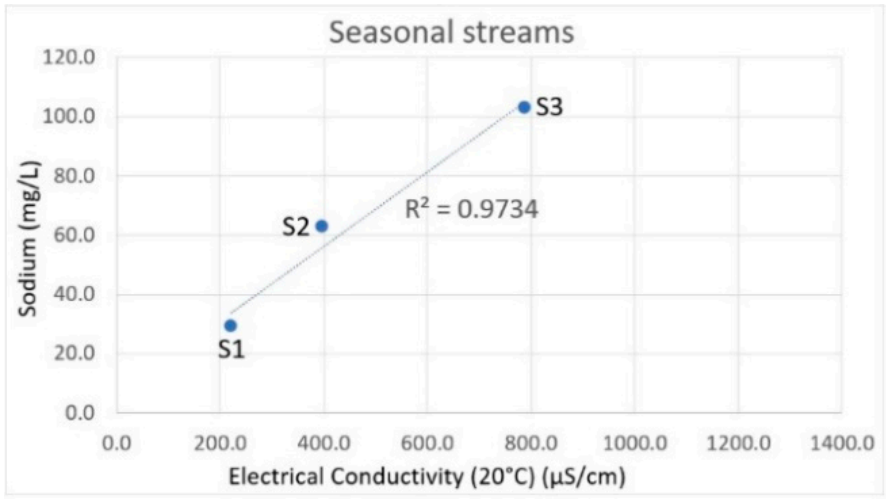

(c)

Figure 15. (a) Chloride vs. sodium graph (meq/L); (b) electrolytic conductivity vs. chlorides graph; (c) electrolytic conductivity vs. sodium graph for the surface analyzed waters. 
New data have to be added in order to verify the indicative trends obtained.

Chemical data were also plotted in the Piper diagram, allowing for a classification of groundwater and surface water in chemical facies and for a simultaneous comparison of different water samples. The Piper diagram (Figure 16) shows that the samples belong to the Na-HCO3 facies. These waters are typical of deep groundwater environments, influenced by ion exchange.

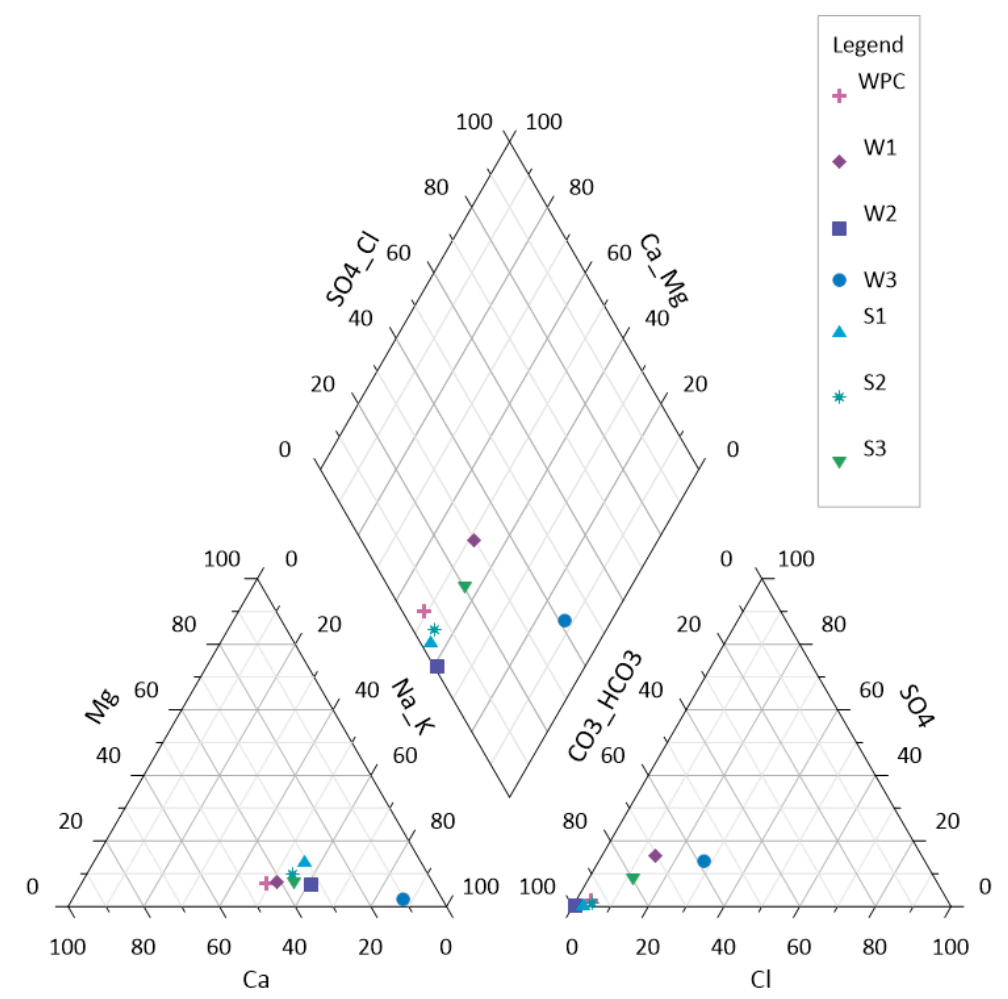

Figure 16. Piper diagram, showing hydrochemical facies of groundwater and surface water samples.

The Na-rich facies resulting from the Piper classification is coherent with the high concentration of sodium that slightly exceeds the national regulation in three groundwater samples out of four. The remaining sample (W2) has, however, an Na concentration of $98.8 \mathrm{mg} / \mathrm{L}$ (the limit is $100 \mathrm{mg} / \mathrm{L}$ ).

Nevertheless, according to the experimental results, this high sodium concentration is not related to an equivalent abundance of chlorides (i.e., the correlation between sodium and chlorides is unbalanced in favor of sodium). The hypothesis of an anthropic contamination that could be considered in presence of salty waters (i.e., similar concentrations of $\mathrm{Na}$ and $\mathrm{Cl}$ ) seems therefore to be unsuitable in this case, suggesting, rather, a natural origin. The described geological framework, reporting a regional bedrock mainly consisting of granite rocks rich in $\mathrm{Na}$ minerals (e.g., albite and Na feldspars) supports this hypothesis. Similar results and conclusions were obtained by the author of [23], who proposed an analysis of the water pollution in Sudan (i.e., in the northern geographical position with respect to our study area) and observed a prevalence of sodium bicarbonate water facies where the aquifer was in contact with the rock basement.

A similar natural origin of water pollution may be suggested for the fluorides that exceed the national regulation limits in the majority of the samples. Fluoride was, indeed, described as one of the most important natural pollutants of water in Africa [24] as a consequence of volcanic activities, presence of thermal waters, gases emissions and granitic and gneissic rocks. These natural conditions are often enhanced by low pumping rates, which increase the contact time and favor water-rock interactions, resulting in higher fluoride releases in groundwater [24,25].

As already stated, the concentration of total chromium, which exceeds the WHO limits in three of the samples, is related to a low percentage $(<5 \%)$ of hexavalent chromium (i.e., the chromium form 
usually linked to anthropic contamination and more dangerous for the human health). This suggests, again, a natural origin of the contamination connected with lithological setting (i.e., presence of granite or gneiss rocks)

The last anomalous record in the results involves sample W2, which has a content of manganese that slightly exceeds the national regulations and is significantly higher than in all the other samples. Since the depth of the W2 well is not significantly different from the others, this anomalous concentration should be attributed to local conditions. The absence of nitrates and sulphates and the low electrolytic conductivity that characterize this water sample suggest the existence of a reducing environment, possibly connected to an organic contamination that progressively introduces a dissolution of manganese (and iron) already present in the surrounding rocks.

\section{Conclusions}

The groundwater resources of a country are crucial for the development of several economic sectors. In semi-arid and arid environments, groundwater enables millions of human beings and animals to exist in terrains that would otherwise be uninhabitable.

The General Assembly of the United Nations published the document "Transforming our world: the 2030 Agenda for Sustainable Development" as a result of the UN summit for the adoption of the post-2015 development agenda. In terms of the Sustainable Development Goal target for drinking water, Sustainable Development Goal (SDG) target 6.1 is to "achieve universal and equitable access to safe and affordable drinking water for all by 2030".

The availability and quality of water, besides representing a fundamental resource as drinking water, is necessary for a good development of agricultural and breeding activities and, consequently, for a sustainable development of the local economy. The water shortage, together with the great frequency and severity of drought periods and the excessive heat conditions, often causes agricultural vulnerability in arid or semi-arid areas of Sub-Saharan Africa. These conditions of vulnerability are enhanced by the global climate changes of recent years, the effects of which are expected to be large and far-reaching predominantly in the developing world [26,27].

For these reasons, the present study proposes an investigation of the lithostratigraphic and hydrogeological setting of the Gumbo village (SE of Juba) to make water extraction systems available and ensure their sustainable management to guarantee food security and economic independence for the populations in the area. Due to the political and social instability, the possibility to move and work in the field during the project was negatively affected, implying the difficulty of collecting data and water samples. Nevertheless, considering the scarce scientific and technical literature available for South Sudan, the collected data and proposed interpretations represent a first fundamental step for the characterization of the Gumbo area. The results contribute to defining a conceptual hydrogeological model and the critical aspects to take into account for the water use in the sampled sites.

In any context, the knowledge of the hydrogeological and hydrochemical setting is an important prerequisite for a risk-informed management of water resources. The planning of hydrogeological-based interventions may guarantee a wide access to good quality water for the local population for drinking, irrigation and livestock purposes. This study represents, therefore, a fundamental step to ensuring food security as well as sustainable economic development and social progress in this African region.

The collected data can be very useful for Administrative Local Authorities, recently established in South Sudan, as well as researchers and the local population, in order to improve water knowledge and management in this little-known area. Moreover, the implementation of a scientific dataset represents the first step toward sustainable economic development and social progress, helping to improve the livelihood of the rural communities and enhancing sustainable and environmentally friendly agriculture, soil conservation and remunerable livestock.

According to the Local Authorities, a survey program increasing the number of water points to monitor the quantitative and qualitative distribution of the water resource should help in better defining the local knowledge gained in the present study and consolidating the scenario that is 
defined (higher quality of groundwater than surface water, "productive borehole in fractured zone" hydrogeological model and natural contaminations due to a geological setting with local increasing of exceeding parameters).

Future developments of the study may also include the long-term monitoring of the groundwater. The repetition of the analyses proposed in this study (i.e., measure of groundwater static level, hydrochemical analyses of surface and groundwater samples) at different times throughout the year, together with an increase of the number of sampling points, may allow for the assessment of the real potential of the water resource, with an evaluation of the influence of the seasonal variations on the resource availability. The temporal and spatial increment of collected samples would also contribute to validating the hydrogeological model, with an improved understanding of the flow directions and of the relations between groundwater and surface waters.

Further information should moreover include socioeconomic and demographic data (population, land use, cultivated crops, livestock activities, etc.) of the study area to better understand the various human needs for water to neither exhaust the water sources and the local economy nor have long term negative impact on the environment.

In addition, the monitoring of the chemical contaminations over time, possibly enriched with the local sampling of waters at different depths, may quantify the real danger related to each anomalous concentration and explain the distribution of the contaminations in the aquifer [28,29]. As a function of the specific use (e.g., drinking water, agriculture), the results of these analyses may help to assess the necessity and the features of interventions that may guarantee the safe use of the water resource.

In relation to the intended use of water for agricultural purposes, additional analyses may be specifically directed to the evaluation of the sodium adsorption ratio (SAR), which is a good indicator of the suitability of water for irrigation.

Due to the dry climate conditions of South Sudan, and of the Sub-Saharan African regions in general, another important development of the research could be the assessment of water resources' vulnerability to climate change [30]. An interesting approach to investigate this topic is the analysis of the water resource potential; after the selection of a number of target stations, the study should provide an estimation of rainfall amount on average over the last 30 years and a comparison of rainfall data and survey campaign outputs. The results would show whether the climate change affected the groundwater, with a quantitative evaluation of the entity of this influence on both availability and quality of the water resource [31,32].

A similar development of the research should represent the first step to defining Local Development Territorial Plans that the government needs in order to identify sustainable social and economic assessment (economic activities to encourage, territorial distribution of the refugees, stabilization or development of nomadism). It would be recommended for all decision-makers and politicians but also for rural development program managers to employ a similar approach, which emphasizes the knowledge of the characteristics of the territory and its specificities to deal with the management of natural resources, water in particular, in a sustainable way.

Author Contributions: Conceptualization, M.L. and S.M.R.B.; data curation, L.D., C.C. and C.S.; formal analysis, M.L. and S.M.R.B.; funding acquisition, S.M.R.B.; Investigation, L.D.; methodology, M.L. and S.M.R.B.; supervision, D.A.D.L.; visualization, C.C. and C.S.; writing-original draft, M.L., S.M.R.B., C.C. and C.S.; writing-review \& editing, M.L. and S.M.R.B. All authors have read and agreed to the published version of the manuscript.

Funding: This research was funded by AICS (Agenzia Italiana per la Cooperazione allo Sviluppo), OSC-2016 competition, grant number AID 10915/VIDES/SSD, Title of the project “Women Empowerment and Sustainable Agriculture Development to Achieve Food Security in South Sudan (WOSA)".

Acknowledgments: The authors thank Comina Cesare for his help in the interpretation of geophysical data.

Conflicts of Interest: The authors declare no conflict of interest. 


\section{References}

1. Bonetto, S.; Facello, A.; Camaro, W.; Cristofori, E.I.; Demarchi, A. An approach to integrate spatial and climatological data as support to drought monitoring and agricultural management problems in South Sudan. In Proceedings of the EGU General Assembly, Vienna, Austria, 17-22 April 2016.

2. Anudu, G.K.; Essien, B.I.; Onuba, L.N.; Ikpokonte, A.E. Lineament analysis and interpretation for assessment of groundwater potential of Wamba and adjoining areas, Nasarawa State, north-central Nigeria. J. Appl. Technol. Environ. Sanit. 2011, 1, 185-192.

3. Ayenew, T.; Demlie, M.; Wohnlich, S. Hydrogeological framework and occurrence of groundwater in the Ethiopian aquifers. J. Afr. Earth Sci. 2008, 52, 97-113. [CrossRef]

4. Bonetto, S.; De Luca, D.; Lasagna, M.; Lodi, R. Groundwater distribution and fluoride content in the West Arsi Zone of the Oromia Region (Ethiopia). In Engineering Geology for Society and Territory, Volume 3: River Basins, Reservoir Sedimentation and Water Resources; Lollino, G., Arattano, M., Rinaldi, M., Giustolisi, O., Marechal, J.-C., Grant, G.E., Eds.; Springer: Berlin/Heidelberg, Germany, 2015; pp. 579-582.

5. Bonetto, S.; Facello, A.; Cristofori, E.I.; Camaro, W.; Demarchi, A. An Approach to Use Earth Observation Data as Support to Water Management Issues in the Ethiopian Rift. In Climate Change Adaptation in Africa. Climate Change Management; Springer: Berlin/Heidelberg, Germany, 2017; pp. 357-374.

6. Bonetto, S.; Facello, A.; Umili, G. The contribution of Curva Tool semi-automatic approach in structural and groundwater investigations. A case study in the Main Ethiopian Rift Valley. Egypt. J. Remote Sens. Space Sci. 2018, 23, 97-111. [CrossRef]

7. Rango, T.; Bianchini, G.; Beccaluva, L.; Tassinari, R. Geochemistry and water quality assessment of central Main Ethiopian Rift natural waters with emphasis on source and occurrence of fluoride and arsenic. J. Afr. Earth Sci. 2010, 57, 479-491. [CrossRef]

8. Yenne, E.Y.; Anifowose, A.Y.B.; Dibal, H.U.; Nimchak, R.N. An assessment of the relationship between lineament and groundwater productivity in a part of the basement complex, Southwestern Nigeria. IOSR J. Environ. Sci. Toxicol. Food Technol. 2015, 9, 23-35.

9. Lasagna, M.; Dino, G.A.; Perotti, L.; Spadafora, F.; De Luca, D.A.; Yadji, G.; Tankari, D.-B.A.; Moussa, I.; Harouna, M.; Moussa, K. Georesources and environmental problems in Niamey city (Niger): A preliminary sketch. Energy Procedia 2015, 76, 67-76. [CrossRef]

10. Bucci, A.; Franchino, E.; De Luca, D.A.; Lasagna, M.; Malandrino, M.; Bianco, P.A.; Hernandez, S.H.O.; Macario, C.I.; Sac, E.E.; Hernandez, A. Ground water chemistry characterization using multi-criteria approach: The upperSamala River basin (SW Guatemala). J. South Am. Earth Sci. 2017, 78, 150-163. [CrossRef]

11. UNITED NATIONS. Available online: https://www.un.org/Depts/Cartographic/map/profile/southsudan.pdf (accessed on 3 December 2019).

12. Appelo, C.A.J.; Postma, D. Geochemistry, Groundwater and Pollution; Balkema: Rotterdam, The Netherlands, 1996.

13. WHO. Guidelines for Drinking-Water Quality, 4th ed.; WHO Library Cataloguing-in-Publication Data: Geneva, Switzerland, 2011.

14. Nile Basin Initiative (NBI), Initiative du Bassin du Nil. State of the River Nile basin. 2012. Available online: https://www.nilebasin.org/documents-publications (accessed on 7 December 2019).

15. Climate and Average Weather in South Sudan. Available online: http://www.weather-and-climate.com (accessed on 4 June 2019).

16. EISOURCEBOOK. Good-Fit Practice Activities in the International Oil, Gas \& Mining Industries-South Sudan. Available online: http://www.eisourcebook.org/1250_SouthSudan.html (accessed on 6 June 2019).

17. Vail, J.R. Outline of the Geochronology and tectonic units of the basement complex of Northeast Africa. Proc. R. Soc. Lond. Ser. A 1976, 350, 127-141.

18. Vail, J. Research in Sudan, Somalia, Egypt and Kenya. J. Afr. Earth Sci. 1990, 11, 231-232. [CrossRef]

19. Vail, J.R.; Kuron, J. High level igneous emplacements in the Red Sea Hills, Sudan. Geol. Rundsch. 1978, 67, 521-530. [CrossRef]

20. Adak, S.M. The Geology of Juba and the Surrounding Area, Central Equatoria; University of Juba: Juba, South Sudan, 2015.

21. Vrba, J.; Richts, A. The Global Map of Groundwater Vulnerability to Floods and Droughts. Explanatory Notes; UNESCO: Paris, France, 2015. 
22. Ministry of Electricity, Dams, Irrigation \&Water Resources of the Republic of South Sudan. Irrigation Development Master Plan (Final Report)—Annex 3: Irrigation Development Potential Assessment; Ministry of Electricity, Dams, Irrigation \&Water Resources of the Republic of South Sudan: Juba, South Sudan, 2005.

23. Abdo, G. Status of Groundwater Quality and Pollution Risk in Sudan. Groundwater Protection Network in the Arab Region; IHP Publication: No 14; UNESCO CAIRO Office: Paris, France, 2003.

24. Malago, J.; Makoba, E.; Muzuka, A.N.N. Fluoride Levels in Surface and Groundwater in Africa: A Review. American. J. Water Sci. Eng. 2017, 3, 1-17. [CrossRef]

25. Schmoll, O.; Howard, G.; Chilton, J.; Chorus, I. Protecting Groundwater for Health-Managing the Quality of Drinking-Water Sources; World Health Organization (WHO): London, UK, 2006.

26. Altieri, M.A.; Nicholls, C.I. The adaptation and mitigation potential of traditional agriculture in a changing climate. Clim. Chang. 2017, 140, 33-45. [CrossRef]

27. Meijer, S.S.; Catacutan, D.; Ajayi, O.C.; Sileshi, G.W.; Nieuwenhuis, M. The role of knowledge, attitudes and perceptions in the uptake of agricultural and agroforestry innovations among smallholder farmers in sub-Saharan Africa. Int. J. Agric. Sustain. 2015, 13, 40-54. [CrossRef]

28. Lasagna, M.; De Luca, D.A. The use of multilevel sampling techniques for determining shallow aquifer nitrate profiles. Environ. Sci. Pollut. Res. 2016, 23, 20431-20448. [CrossRef]

29. Chapman, S.; Parker, B.; Cherry, J.; Munn, J.; Malenica, A.; Ingleton, R.; Jiang, Y.; Padusenko, G.; Piersol, J. Hybrid multilevel system for monitoring groundwater flow and agricultural impacts in fractured sedimentary bedrock. Groundw. Water Monit. Remediat. 2015, 35, 55-67. [CrossRef]

30. Caselle, C.; Bonetto, S.; De Luca, D.A.; Lasagna, M.; Perotti, L.; Bucci, A.; Bechis, S. An interdisciplinary approach to the sustainable management of territorial resources in Hodh el Chargui, Mauritania. Sustainability 2020, 12, 5114. [CrossRef]

31. Lasagna, M.; Ducci, D.; Sellerino, M.; Mancini, S.; De Luca, D.A. Meteorological variability and groundwater quality: Examples in different hydrogeological settings. Water 2015, 12, 1297. [CrossRef]

32. Fallahati, A.; Soleimani, H.; Alimohammadi, M.; Dehghanifard, E.; Askari, M.; Eslami, F.; Karami, L. Impacts of drought phenomenon on the chemical quality of groundwater resources in the central part of Iran-Application of GIS technique. Environ. Monit. Assess. 2020, 192, 64. [CrossRef] [PubMed] 